\title{
Analysis of insulin receptors on heterogeneous eukaryotic cell populations with fluorochrome-conjugated insulin and fluorescence-activated cell sorter. Advantages and limitations to the ${ }^{125} \mathrm{I}$-labelled insulin methodology
}

\author{
C. Due ${ }^{1}$, K. Linnet ${ }^{1}$, N. Langeland Johansen ${ }^{2}$ and L.Olsson ${ }^{1}$ \\ 'Cancer Biology Laboratory, Medical Department A, State University Hospital, Copenhagen, and ${ }^{2}$ Novo Research Institute, Bagsværd, Denmark
}

\begin{abstract}
Summary. The diversity in insulin receptor expression within eukaryotic cell populations can be studied with fluorochrome conjugated reagents with high affinity to the insulin receptor in combination with flow cytometry. We studied the optimal conditions for application of fluorescein isothiocyanate (FITC) conjugated insulin in combination with the fluorescence activated cell sorter (FACS) to analyse insulin receptor expression, and also studied the feasibility of this method for identifying and isolating viable subsets with differences in insulin receptor expression within a cell population. Semisynthetic human insulin was conjugated to FITC, which resulted in at least four types of FITC-insulin molecules with different affinities to the insulin receptor. Each type of FITC-insulin was isolated by semipreparative reverse phase high pressure liquid chromatography. The preparation with a fluorescein/ protein ratio of $\sim 1.0$ was found to have the highest affinity to the receptor, the highest biological activity $(\sim 50 \%$ of native insulin), and similar antigenicity as native insulin. The optimal staining conditions with respect to $\mathrm{pH}$, time of incubation, and cell number were determined, and were different in some aspects from labelling with ${ }^{125}$ I-insulin. The binding of FITCinsulin to cells was saturable and could be displaced with unlabelled insulin. The fluorescence signal could be converted to
\end{abstract}

absolute numbers of fluorescein molecules by a calibration curve, and the absolute number of specifically bound FITCinsulin molecules calculated from a $\mathrm{F} / \mathrm{P}$ ratio $\sim 1.0$. The FITC-insulin/FACS method permits estimation of the total number of insulin receptors (high plus low affinity), and the data obtained correlate well with the results from Scatchard plot of ${ }^{125}$ I-insulin binding data. However, the latter method also permits selective detection of the number of high affinity insulin receptors, which cannot be done with FITC-insulin/ FACS that has a lower level for detection of fluorescence on $\sim 2000$-3000 fluorescein molecules per cell. The FITC-insulin/FACS methodology permitted identification and isolation of viable cellular subsets within a cell population as based on the number of insulin receptors and was also used to study variations in insulin receptor density in human leucocytes. The method should make it possible to perform a number of hitherto unfeasible analyses of the biology of insulin receptor expression on eukaryotic cells.

Key words: Insulin receptors, fluorescein-conjugated insulin, fluorescence activated cell sorter analysis, heterogeneity in insulin receptor density.
Phenotypic diversification has been described within clonal derived populations of both normal and malignant cells [1]. Identification and isolation of subsets of cells with respect to a cell constituent should in principle be feasible by fluorescence activated cell sorter (FACS) analysis/sorting of cells stained with a fluorochrome conjugated reagent with high binding affinity for the constituent. Antibodies with specificity for cell membrane antigens have in particular been used as such reagents, and this has been reinforced by the development of monoclonal antibody technology [2].

Expression of hormone receptors has typically been estimated by Scatchard plot [3] of the data for binding of radiolabelled hormone to the cells, although Scatch- ard analysis only has limited value in a number of situations [4]. Moreover, a curvilinear Scatchard plot is consistent with either multiple classes of insulin receptors or site-site interactions of the type known as negative cooperativity [5]. However, it might also reflect the presence of subsets of cells with different receptor density within the cell population. Heterogenicity in insulin receptor expression cannot be explored with radiolabelled ligand, which measures the average receptor expression of the cell population. It is accordingly of importance to develop methods that permit identification and further investigation of subsets of cells with different hormone receptor expression within a cell population. 
Fluorochrome (e.g. fluorescein isothiocyanate, FITC) conjugated lectins have been used in combination with flow cytometry to evaluate their binding to cells $[6,7]$. However, the conditions for application of FITC-lectins, e.g. FITC-concanavalin A, cannot readily be used for specific hormones like insulin, partly because the biochemical structures of lectins are very different from peptide hormones, and partly because a lectin like concanavalin A binds to a number of different glycoproteins with approximately the same affinity, whereas a peptide hormone binds with high affinity only to its specific receptor.

A few reports have described the use of FITC $[6,8]$ or rhodamin $[9,10]$ conjugated insulin. Some of these analyses have also applied flow cytometry. However, none of these reports give detailed data for the conditions for the labelling of cells with FITC-insulin (e.g. $\mathrm{pH}$, incubation time), the structural alteration of insulin by FITC-conjugation (e.g. altered antigenicity). In addition, no direct comparison between FITC-insulin data and ${ }^{125} \mathrm{I}$-insulin data has been done. A few of the reports $[8,9,10]$ have indicated that fluorochrome conjugation resulted in reduction of the biological activity of insulin to $\sim 1.15 \%$ of native insulin. High purification of FITC-insulin with high biological activity and binding affinity seemed therefore desirable prior to its use in combination with flow cytometry (FITC-insulin/ FACS).

We have, therefore, purified FITC conjugated insulin by reverse phase high pressure liquid chromatography and obtained a FITC-insulin preparation with a fluorescein/protein $(\mathrm{F} / \mathrm{P})$ ratio $\sim 1.0$ and with $\sim 50 \%$ biological activity and binding affinity as compared to native insulin. The conditions for staining of cells with FITC-insulin ( $\mathrm{pH}$, incubation time, cell number) and the antigenicity of FITC-insulin as compared to native insulin is described. The total number of insulin receptors on various eukaryotic cells was measured by FITCinsulin/FACS and by ${ }^{125}$ I-insulin labelling, respectively, and the feasibility of the FITC-insulin/FACS method to identify subsets of cells with different insulin receptor expression was demonstrated in a population of mononuclear blood leucocytes (lymphocytes and monocytes). The FITC-insulin method could be applied both to fixed and viable cells.

\section{Materials and methods}

\section{Sources of cell material}

Peripheral blood leucocytes were obtained from 20-40-years-old volunteers in the laboratory. The mononuclear cells were isolated on a Ficoll-hypaque gradient and washed free of insulin as previously described [11] before incubation with FITC-insulin. No attempts were made to isolate the monocyte fraction prior to staining, as monocytes could be distinguished from lymphocytes by the FACS scatter signals [12]. Viability as assessed by trypan blue dye exclusion was $>95 \%$, and $\mathrm{pH}$ remained stable during the incubation period.
Human cell lines were: U-937 (histiocytic lymphoma; [13]), HL-60 (promyelocytic leukemia; [14]), RH-LA (B-lymphoma; [15]), Daudi (Burkitt lymphoma; [16]) and IM-9 (lymphoblastoid cells; [17]). All lines were maintained in RPMI-1640 medium with $10-15 \%$ fetal calf serum (FCS), supplemented with $0.3 \%$ fresh glutamin, at $37^{\circ} \mathrm{C}$ with $95 \%$ atmospheric air and $5 \% \mathrm{CO}_{2}$. Only cells in the exponential growth phase were used.

In some experiments, spleen cells from 4-6 week-old female $\mathrm{Balb} / \mathrm{c}$ mice were used. The mice were obtained from our own specific pathogen-free colony and maintained under standard conditions with water and food ad libitum.

\section{Hormone preparations}

Semisynthetic human insulin, ${ }^{125} \mathrm{I}$-conjugated insulin (conjugated at Tyr-A14: specific activity $200-300 \mu \mathrm{Ci} / \mu \mathrm{g}$ ), purified A- and B-chains of insulin, and glucagon were all obtained from Novo Industry $A / S$, Bagsværd, Denmark. FITC (Sigma, lot No.102F5045) conjugation was done at room temperature by the following procedure: $100 \mathrm{mg}$ to $1 \mathrm{~g}$ insulin was dissolved in phosphate buffered saline (PBS) to a concentration of $10 \mathrm{mg} / \mathrm{ml}$ and the solution adjusted to $\mathrm{pH} 9$ with a $0.5 \mathrm{M}$ bicarbonate/carbonate buffer. FITC was dissolved in dimethyl sulfoxide (DMSO) to a concentration of $4 \mathrm{mg} / \mathrm{ml}$ and added dropwise under constant stirring to the insulin solution $(5 \mu$ FITC per $\mathrm{mg}$ insulin). The mixture was incubated in the dark for $2 \mathrm{~h}$ and free FITC separated from insulin and FITC-insulin on a G-25 sephadex column (Pharmacia, Uppsala, Sweden) equilibrated with PBS (pH 7). Fifty to one hundred $\mathrm{mg}$ insulin and FITC-insulin were separated into five fractions by semipreparative reverse phase HPLC on a $10 \mathrm{~mm} \times$ $250 \mathrm{~mm}$ column of $7 \mu \mathrm{C}-18$ derivatised silica (Merck No.50994). The column was eluted at $6 \mathrm{ml} / \mathrm{min}$ with $0.2 \mathrm{M}\left(\mathrm{NH}_{4}\right)_{2} \mathrm{SO}_{4}, \mathrm{pH} 3$, using a gradient from $20 \%$ to $45 \%$ acetonitrile during $20 \mathrm{~min}$. Unchanged insulin eluted at $15.8 \mathrm{~min}$ followed by four different fluorescein labelled insulins eluting at $17.8 \mathrm{~min}, 18.3 \mathrm{~min}, 19.2 \mathrm{~min}$, and $21.0 \mathrm{~min}$, respectively. The fractions were collected, the acetonitrile removed on a rotary evaporator, and the remaining solution adjusted to $\mathrm{pH} 7$. The fraction eluting at $19.2 \mathrm{~min}$ had a $F / P$ ratio of 0.98 as estimated from spectrophotometric measurements at 280 nanometers (peptide) and at $495 \mathrm{~nm}$ (fluorescein). And FITC is under these conditions almost exclusively conjugated to phenylalanin in the B-chain (Bl) [18]. This fraction had the highest affinity to insulin receptors, was displacable with native insulin, and had high biological activity (see below). It was therefore used in all experiments.

\section{Labelling of cells with FITC-insulin or ${ }^{125}$ I-insulin}

One million cells were suspended in $300 \mu$ PBS containing FITC-insulin $\left(0.1 \mu \mathrm{g} / \mathrm{ml}\right.$ unless otherwise stated) for up to $120 \mathrm{~min}$ at $17^{\circ} \mathrm{C}$. In some experiments cold insulin was added in various concentrations. The incubation was done on a rocking platform to avoid sedimentation and was terminated by washing the cells twice in ice cold PBS with subsequent fixation in a $0.5 \%$ formaldehyde solution. The staining pattern remained stable for 7-14 days after fixation, when the cells were stored at $0-4^{\circ} \mathrm{C}$ (Fig. 1). In some cases, the cells were FACS analysed immediately after staining and thus without fixation. Formaldehyde fixation did not change fluorescence intensity as compared to viable cells.

The assay with ${ }^{125} \mathrm{I}$-insulin was performed as described elsewhere [19]. One to six million cells per ml were incubated in RPMI-1640 medium, $\mathrm{pH} 7.6$, with $20 \mathrm{pM}^{125} \mathrm{I}$-insulin and in the absence or presence of unlabelled insulin in concentrations from $10 \mathrm{pM}$ to $3 \mu \mathrm{M}$. Nonspecific insulin binding was defined as the amount of ${ }^{125} \mathrm{I}$-insulin bound to cells in the presence of a large excess $(3 \mu \mathrm{M})$ of unlabelled insulin and did not exceed $2 \%$. All samples were run in triplicates.

\section{Assay for biological activity of insulin}

The biological activity of semisynthetic human insulin and FITC-insulin was measured by incorporation of ${ }^{3} \mathrm{H}$-deoxy-glucose into lipids of isolated fat cells [20]. 


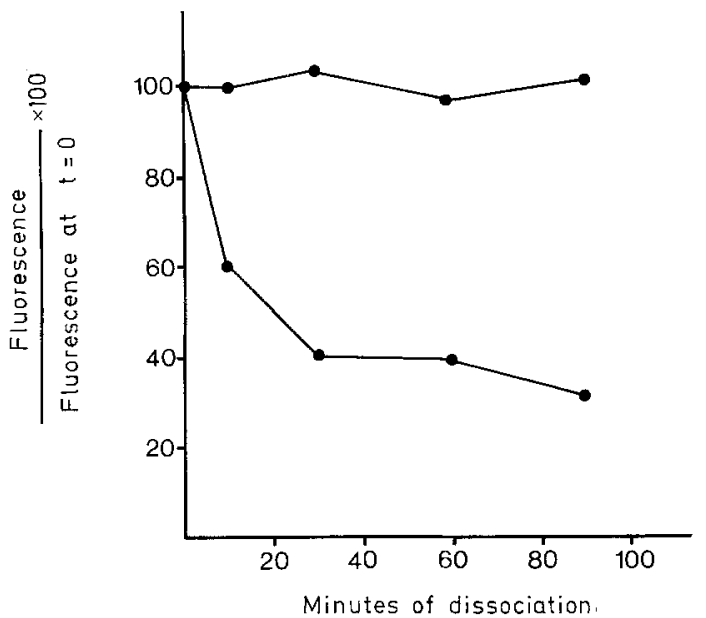

Fig. 1. Effect of fixation in $0.5 \%$ formaldehyde on the dissociation of FITC-insulin. FITC-insulin $0.1 \mu \mathrm{g} / \mathrm{ml}$ was incubated with $\mathrm{U} 937$ cells $\left(3.33 \times 10^{6} / \mathrm{ml}\right)$ for $90 \mathrm{~min}$ at $17^{\circ} \mathrm{C}$ and $\mathrm{pH} 7$. The cells were washed twice in PBS. Some cells were fixed in $0.5 \%$ formaldehyde $(O)$ and other cells were resuspended in PBS (- Four tubes of each set were analysed by FACS for each time point. The mean fluorescence on cells, expressed as a percentage of the fluorescence at time $(t)=O$ is plotted as a function of time. Each point is the mean of quadruplicates which differed less than $12 \%$

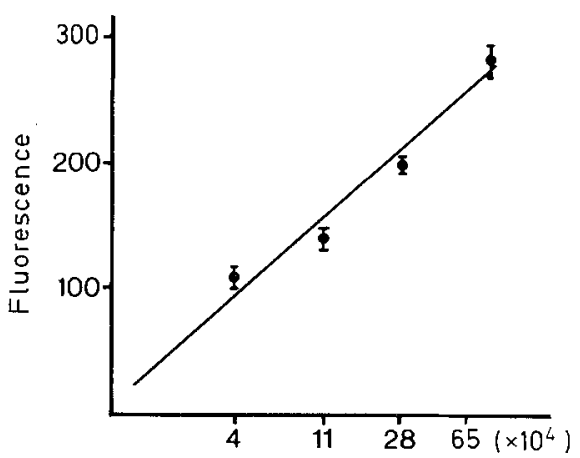

FITC molecules/particle

Fig. 2. Calibration curve for the relationship between the fluorescence channel number and number of fluorescein molecules. Latex particles with a known mean number of FITC-molecules per particle were FACS analysed and the mean channel number plotted as a function of fluorochromes per particle. The curve was constructed as the best fit of a straight line to the experimental data by the least square method. Each value represents mean of triplicate measurements. Bars represent SD

\section{Anti-insulin antibodies}

Polyclonal antibodies against insulin of human, porcine, and bovine insulin were obtained from Novo Industry A/S, Bagsværd, Denmark. Human anti-insulin receptor antibodies [21] were provided from Dr. J. Nerup, Steno Memorial Hospital, Gentofte, Denmark.

Murine monoclonal antibodies were generated against insulin. Briefly, 4-6-week-old $\mathrm{Balb} / \mathrm{c}$ mice were immunized with bovine insu$\operatorname{lin}(15 \mu \mathrm{g}$ s. c. per injection). Four days after the last of five injections, mononuclear spleen cells were fused with the X63. Ag8.6.5.3 murine myeloma cells according to procedures described previously [15]. Supernatants were screened for reactivity to bovine, porcine, and semisynthetic human insulin by ELISA, positive cultures were cloned twice by limiting dilution, and monoclonality of relevant cultures as- sured by $2 \mathrm{D}$-analysis of ${ }^{35} \mathrm{~S}$-methionine labelled Ig-products. Seven hybridoma clones with reactivity against insulin were established as ascites tumours in mice, and Ig purified from the ascites fluid.

The reactivity of the polyclonal antibody to insulin and FITC-insulin was analysed in an Ouchterloney test [22]. The reactivity pattern of the monoclonal antibodies was tested by ELISA in a 96-well plate. Plates coated with $1 \mu \mathrm{g}$ per well of insulin or FITC-insulin were incubated for $3 \mathrm{~h}$ at room temperature with $10 \mu \mathrm{g}$ antibody. Free sites were coated with $1 \%$ FCS/PBS. The plate was washed five times in PBS, and rabbit anti-mouse Ig conjugated with alkaline phosphatase used as second step reagent.

\section{Light and electron microscopy}

Cytocentrifuge preparations were made of cells and stained with Giemsa-Wright stain to test for morphological alterations as a function of exposure to insulin. Cells for electron microscopy were centrifuged to a pellet, fixed in $2 \%$ glutaraldehyde, and processed. Incubation of cells with insulin $(10 \mu \mathrm{g} / \mathrm{ml})$ and FITC-insulin $(0.1-0.5 \mu \mathrm{g} / \mathrm{ml})$ did not result in morphological alterations of the cells.

\section{FACS analysis}

All FACS analyses were performed with a FACS IV (Becton-Dickinson, Mt. View, Ca.). The instrument operates with an argon-laser (Model 164-05, Spectraphysics), which was used with a wavelength at $488 \mathrm{~nm}$. A neutral density filter $(1 \%)$ was used for the scatter signal and for the fluorescence signal a $530-\mathrm{nm}$ filter. Five or ten thousand cells were analysed per sample at a rate of 500-3000 cells per second and with a nozzletip with $80 \mu \mathrm{m}$ in diameter. The trigger signal was determined by the scatter signal. A program was developed that permits transfer of all scatter and fluorescence signals for each cell to a HP 9836 computer (Hewlett-Packard, Palo Alto, Ca), which permits a detailed data analysis of subpopulations, whenever needed. A calibration curve for the relationship between the FACS signal as measured by arbitrary channel number, and the absolute number of FITC molecules was established every time a set of cell samples was analysed. The following FITC conjugated latex particles (provided by Becton Dickinson, Mt. View, Ca) were used: (1) bead diameter $4.3 \mu \mathrm{m}$, scatter cv $2 \%$, fluorescence cv 10\%, $4.2 \times 10^{4}$ FITC molecules/bead; ( 2 ) bead diameter $5.3 \mu \mathrm{m}$, scatter cv $2 \%$, fluorescence cv $10 \% .10 .8 \times 10^{4}$ FITC molecules/bead; (3) bead diameter $6.3 \mu \mathrm{m}$, scatter cv $2 \%$, fluorescence cy $10 \%, 2.8 \times 10^{5}$ FITC molecules/bead; (4) bead diameter $7.8 \mu \mathrm{m}$, scatter cv $2 \%$, fluorescence cv $10 \% ; 6.5 \times 10^{5}$ FITC molecules/ bead. Non-fluorescent beads with a diameter of $6.3 \mu \mathrm{m}$, scatter cv $2 \%$, were also used. The calibration curve should theoretically be a straight line, which was confirmed experimentally (Fig. 2). The establishment of a calibration curve prior to each analysis of a set of samples also permitted the evaluation of short- and long-term FACS drifting, which was found to be insignificant.

\section{Results}

\section{FITC-insulin binding in relation to cell number, $\mathrm{pH}$, and time}

The nonspecific binding of FITC-insulin was estimated by the fluorescence signal of cells stained with FITC-insulin in the presence of an excess $(10 \mu \mathrm{g} / \mathrm{ml})$ of unlabelled insulin (Fig. 3). The mean number of FITC-molecules per cell was derived from the calibration curve (Fig. 2) that for a given fluorescence intensity as indicated by channel number allows conversion of the channel number into an absolute number of fluorescence molecules. The number will also be the number of bound 


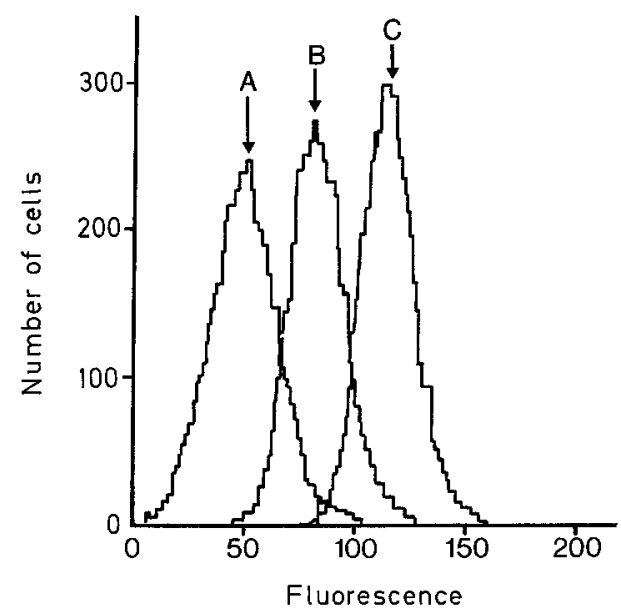

Fig. 3. Fluorescence signals from HL60 cells stained with FITC-insulin $(0.1 \mu \mathrm{g} / \mathrm{ml})$ for $90 \mathrm{~min}$ at $17^{\circ} \mathrm{C}$. The curves are: (A) unstained cells, (B) cells stained with FITC-insulin in the presence of native insulin $(0.1 \mathrm{mg} / \mathrm{ml}),(\mathrm{C})$ cells stained with FITC-insulin in the absence of native insulin. The fluorescence intensity is given in arbitrary channel numbers; each histogram represents the analysis of $\sim 10^{4}$ cells

FITC-insulin molecules, because $\mathrm{F} / \mathrm{P}$ ratio is $\sim 1.0$ and the specific binding is determined as number of FITC molecules bound in the absence of native insulin minus number of FITC molecules bound in the presence of high saturating concentration of native insulin.

The binding of a tracer amount of ${ }^{125} \mathrm{I}$-insulin has been shown to be a linear function of the cell concentration [19]. By incubating various concentrations of cells with $1.0 \mu \mathrm{g} / \mathrm{ml} \mathrm{FITC} \mathrm{insulin} \mathrm{in} 300 \mu 1 \mathrm{PBS}, \mathrm{pH} 7$, no effect of the concentration of cells was observed on the staining intensity of the individual cells in a cell number range of $2 \times 10^{5}$ to $30 \times 10^{5}$ cells $/ 300 \mu$ l. The dosis of $1 \mu \mathrm{g} / \mathrm{ml}$ of FITC-insulin was thus at the saturation lev$\mathrm{el}$, and the number of FITC-insulin molecules bound to a given cell population was therefore directly proportional to the total number of cells in the population. Thus, a peak of fluorescence in channel No. 100 of $10^{6}$ cells and also in channel No. 100 of $2 \times 10^{6}$ cells indicate that the number of FITC molecules bound to $2 \times 10^{6}$ cells is twice the number bound to $10^{6}$ cells. This is in full accordance with ${ }^{125} \mathrm{I}$-insulin data obtained by others [19]. The $\mathrm{pH}$ optimum for binding of FITC-insulin was found to be between 6.5-7.0 (Fig. 4), which is lower than $\mathrm{pH}$ optimum for binding of ${ }^{125}$ I-insulin [5]. Figure 5 shows the specific binding of FITC-insulin as a function of time at $17^{\circ} \mathrm{C}$. Steady state was obtained after about $60 \mathrm{~min}$ and maintained for $30 \mathrm{~min}$.

\section{Displacement of FITC-insulin by unlabelled insulin}

The binding of FITC insulin was displacable with unlabelled insulin (Fig. 6). Slightly more than $60 \%$ of the total fluorescence could be displaced by incubation of cells with native hormone at $10 \mu \mathrm{g} / \mathrm{ml}$. Glucagon and purified A- and B-chains of insulin had no effect on

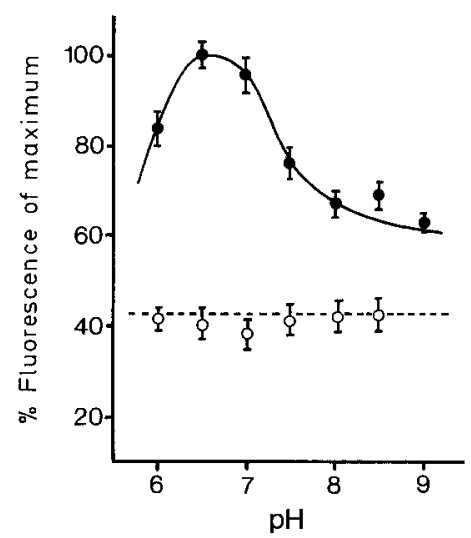

Fig.4. $\mathrm{pH}$ dependence of binding of FITC-insulin to U937 cells. Cells were stained with FITC-insulin $(0.1 \mu \mathrm{g} / \mathrm{ml})$ at various $\mathrm{pH}$ values, fixed in formaldehyde, and FACS analysed. The mean channel numbers were converted to absolute number of fluorescein molecules. The fluorescence is given in per cent of fluorescence at $\mathrm{pH} 6.5$. The dotted line represents unspecific fluorescence. Each point is the result of 2 separate experiments $(n=8)$. Bars indicate SD

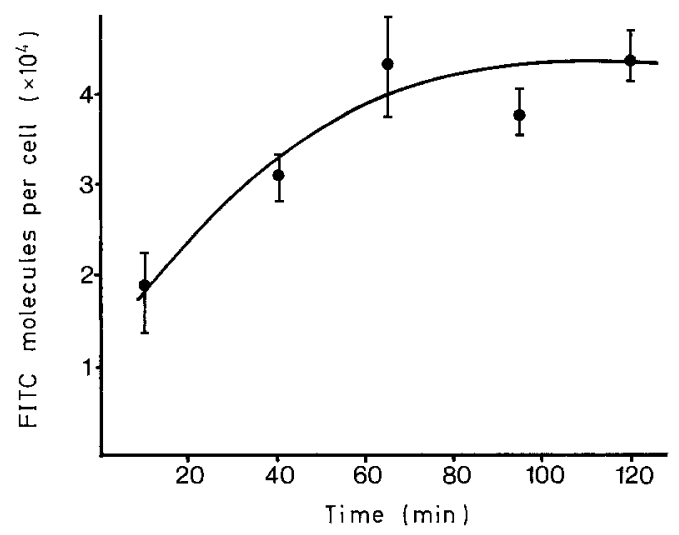

Fig. 5. Specific binding of FITC-insulin to U937 cells as a function of time. U937 cells $\left(10^{6} / 500 \mu \mathrm{l}\right)$ were incubated with FITC-insulin $(0.1 \mu \mathrm{g} / \mathrm{ml})$ in the presence or absence of unlabelled human insulin $(10 \mu \mathrm{g} / \mathrm{ml})$. Cells were analysed by FACS at different time intervals and the specific binding calculated. Each point represents the mean of two experiments. Bars represent SD

FITC-insulin binding. It cannot be completely excluded that a proportion of the $40 \%$ unspecific FITCinsulin was due to internalisation of FITC-insulin, although all experiments were carried out at $16-17^{\circ} \mathrm{C}$.

\section{Antigenic properties of FITC-insulin}

FITC-insulin and native insulin were compared by Ouchterloney analysis using a panel of 9 antisera against insulin of human, porcine, and bovine origin. FITC-insulin and native insulin precipitated identically with 8 of 9 antisera. One serum precipitated only the unlabelled hormone. ELISA-tests with monoclonal antibodies directed against insulin did not show any antigenic differences between FITC-insulin and semisyn- 


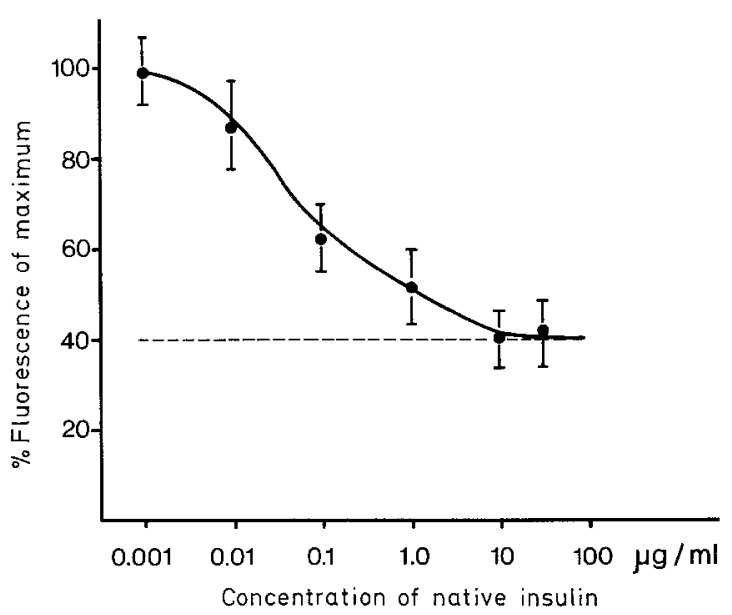

Fig. 6. Inhibition of FITC-insulin binding by unlabelled insulin. $10^{6}$ U937 cells were incubated for $90 \mathrm{~min}$ at $17^{\circ} \mathrm{C}$ with $0.1 \mu \mathrm{g} / \mathrm{ml} \mathrm{FITC}$ insulin in the presence of unlabelled insulin. The cells were fixed in formaldehyde prior to FACS analysis. The mean fluorescence channel numbers were converted to absolute numbers of fluorescein molecules. The fluorescence is given in per cent of maximal binding after subtraction of the fluorescence of unlabelled (autofluorescence) U937 cells. The dotted line indicates unspecific binding. Each point is the mean of 3 separate experiments $(n=12)$. Bars indicate SD

thetic human insulin. The elution patterns of FITC-insulin and native insulin through columns of sepharose, conjugated with monoclonal antibodies against insulin, were identical (data not shown). The FITC insulin preparations were stable for 3 months at $-20^{\circ} \mathrm{C}$ and could be lyophilized without loss of binding ability.

\section{Biological potency and binding affinity of FITC-insulin}

The biological potencies and binding affinities of FITC-insulin and semisynthetic human insulin are summarized in Table 1. FITC-insulin was only $51 \%$ as active as semisynthetic human insulin measured by incorporation of ${ }^{3} \mathrm{H}$-deoxyglucose into lipid of rat adipocytes. The binding affinity of FITC-insulin was $47 \%$ of that of human semisynthetic insulin.

\section{Effect of anti-insulin receptor antibody}

U937 cells were incubated with serum from a patient with insulin receptor antibodies [21], washed 3 times in PBS, incubated in PBS for $1 \mathrm{~h}$ to allow dissociation from the cells of loosely bound serum factors, and finally washed once more before staining with FITC-insulin. Preincubation with receptor antibody resulted in a 55\% reduction in specific fluorescence compared to cells incubated in normal serum that did not influence the FITC-insulin binding (data not shown).

\section{Direct comparison of ${ }^{125}$ I-insulin binding and FITC-insulin binding}

Displacement of ${ }^{125} \mathrm{I}$-insulin by native insulin and subsequent Scatchard analysis (data not shown) indicate that the mean number of receptors per U937 cell $\left(R_{0}\right)$ is about 60,000 receptors. Estimation of the absolute num-
Table 1. Biological activity and binding of FITC-insulin and semisynthetic human insulin

\begin{tabular}{|c|c|c|c|c|}
\hline \multirow[t]{2}{*}{ Hormone } & \multicolumn{2}{|c|}{ Biological activity ${ }^{a}$} & \multicolumn{2}{|c|}{ Binding affinity ${ }^{\mathrm{C}}$} \\
\hline & $\mathrm{ED}_{50}{ }^{\mathrm{b}}$ & $\begin{array}{l}\text { relative } \\
\text { activity } \%\end{array}$ & $\begin{array}{l}\mathrm{IC}_{50}{ }^{\mathrm{d}} \\
\mathrm{pM}\end{array}$ & $\begin{array}{l}\text { relative } \\
\text { affinity } \%\end{array}$ \\
\hline FITC-insulin & & 51 & 596 & 47 \\
\hline $\begin{array}{l}\text { Semisynthetic } \\
\text { human insulin }\end{array}$ & & 100 & 280 & 100 \\
\hline
\end{tabular}

a Isolated rat adipocytes $(2 \mathrm{mg}$ lipid $/ \mathrm{ml})$ were incubated for $2 \mathrm{~h}$ at $37^{\circ} \mathrm{C}$ in Krebs Ringer bicarbonate buffer (1\% albumin), pH 7.4 with $0.5 \mu \mathrm{Ci}{ }^{3} \mathrm{H}$-D-Glucose and various concentrations of FITC-insulin and semisynthetic human insulin. The incorporation of ${ }^{3} \mathrm{H}$-deoxy-glucose in lipids was measured as described elsewhere [20]. ${ }^{b} \mathrm{ED}_{50}=$ Concentration of FITC-insulin or unlabelled hormone that produced half maximal stimulation. ${ }^{\circ} \mathrm{U} 937$ cells $\left(10^{6} / \mathrm{ml}\right)$ and ${ }^{125} \mathrm{I}$-insulin $(20 \mathrm{pmol} / \mathrm{l})$ were incubated with various concentrations of native and FITC-labelled insulin for $90 \mathrm{~min}$ at $17^{\circ} \mathrm{C}$ in RPMI 1640 $\mathrm{pH}$ 7.4. Insulin binding was determined by centrifugation of cells through ice-cold FCS and counting of the pellet radioactivity in a $\gamma$ counter. ${ }^{d} \mathrm{IC}_{50}=$ Concentration of FITC-insulin or unlabelled insulin that inhibited $50 \%$ of the ${ }^{125} \mathrm{I}$-insulin binding in U937 cells

Table 2. Estimated absolute number of insulin receptors on cultured human cells by binding of FITC-insulin or ${ }^{125}$ I-insulin

\begin{tabular}{lll}
\hline Cell line & \multicolumn{2}{l}{ Ligand } \\
\cline { 2 - 3 } & FITC-insulin $^{\mathrm{a}}$ & ${ }^{125}$ I-insulin $^{\mathrm{b}}$ \\
\hline IM-9 & $\sim 140500$ & $\sim 180000$ \\
U 937 & $\sim 40200$ & $\sim 61000$ \\
HL 60 & $\sim 21600$ & $\sim 18200$ \\
RH-L4 & $\sim 1000$ & $\sim 1200$ \\
DAUDI & NS & NS \\
\hline
\end{tabular}

${ }^{a}$ Cells were stained with FITC-insulin $(0.1 \mu \mathrm{g} / \mathrm{ml})$, and the number of receptors was estimated by conversion of the fluorescence signals into absolute numbers of FITC-molecules bound per cell. ${ }^{b}$ Cells were incubated with $20 \mathrm{pmol} / 1^{125} \mathrm{I}$-insulin. The number of receptors was derived from Scatchard graphs. ${ }^{c}$ NS, non-significant specific binding

ber of insulin receptors from FITC-insulin data was done by using a calibration curve, which permits conversion of mean fluorescence to absolute number of fluorescein molecules. The $\mathrm{F} / \mathrm{P}$ ratio of FITC-insulin was 0.98 ; the number of bound insulin molecules $\left(R_{o}\right)$ could therefore be calculated from the absolute number of bound FITC molecules (Table 2). The number of receptors estimated by the two methods correlated well $(r=0.902, p<0.01)$.

\section{Analysis of mononuclear leucocytes by FITC-insulin/FACS}

Mononuclear blood cells comprise both lymphocytes and monocytes that can be distinguished by the scatter signal [12], because monocytes are larger than lymphocytes (Fig.7). The FITC-insulin/FACS method showed that lymphocytes have a low amount of insulin receptors compared with monocytes, which express a significant amount of insulin receptors on the cell surface (Fig.7). The monocyte population comprised in the 


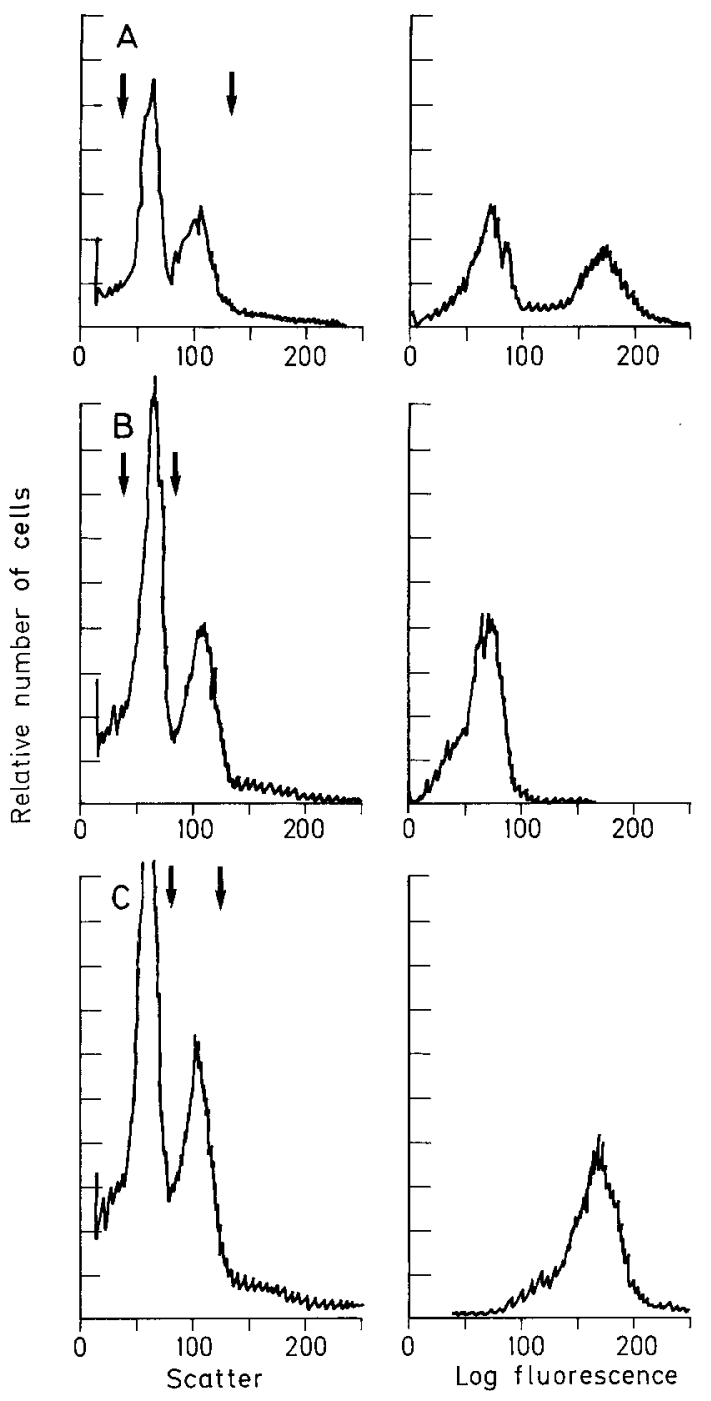

Fig. 7a-c. FACS analysis of monoclear blood leukocytes (PMNc) stained with FITC-insulin. Cells were incubated for $90 \mathrm{~min}$ at $17^{\circ} \mathrm{C}$ with $0.1 \mathrm{\mu g} / \mathrm{ml}$ of FITC-insulin, washed once in ice cold PBS, fixed in $0.5 \%$ formaldehyde, and analysed by FACS. The left histograms indicate scatter signals and the right histograms are the fluorescence signals of these cells that have a scatter signal within the scatter "gate", defined by arrows. a total PMNc population blymphocytes and c monocytes

shown case $\sim 15 \%$ of the total mononuclear peripheral blood cell compartment, but may vary very significantly (from 2-20\%) from individual to individual. A general average number of monocytes in blood is therefore associated with a very large standard deviation.

However, the analyses shown here indicate that cellular subsets with different amounts of insulin receptors within a cell population conveniently may be identified by the FITC-insulin/FACS method.

\section{Discussion}

The complex and heterogeneous binding kinetics of insulin to various types of eukaryotic cells seem related to differences in the amount of insulin receptors, and to differences in the affinity between insulin and the specific receptor [23]. The latter may, on the other hand, partly be a result of variations in the molecular structure of the receptor [23]. Correlations between this variability in insulin receptor expression and other phenotypic features have been difficult to establish, because the traditional methodology for studying insulin receptor expression has been based on labelling with ${ }^{125}$ I-insulin that permits evaluation of the average insulin receptor expression within a cell population, rather than on the single cell level. A number of investigations have, however, clearly demonstrated that even morphologically homogeneous cell populations may be diversified with respect to a number of phenotypic features $[1,24]$. It is therefore highly important that methods be developed to permit studies on insulin receptor expression on the single cell level.

The use of fluorochrome-conjugated insulin has previously been applied to investigations on insulin receptors. Most of these investigations have used FITCinsulin, but data on purification procedures and on the biological characteristics of FITC-insulin are scarce. Bromer et al. [18] reported $\sim 50 \%$ reduction of the biological activity of FITC-insulin preparation as determined by a rat convulsion assay. This finding is in line with the reduction in biological activity of the FITC-insulin preparation used in the present study as measured by glucose incorporation into rat adipocytes. In contrast, other preparations of FITC-insulin or insulin conjugated to rhodamin and lactoalbumin-rhodamin have been reported to have only $1.15 \%$ biological activity and $8.3 \%$ binding affinity compared to native insulin $[9,10]$. Several of these studies have also combined staining of cells with FITC-insulin with flow cytometry $[6,8]$, but none of these reports have in detail described the optimal conditions for staining with FITC-insulin. A few of these reports have provided more detailed data for the binding of FITC-conjugated lectins (in particular Con A), but the binding kinetics of Con A with its high affinity to a number of different glycoproteins cannot readily be deduced as valid for the highly specific binding of insulin to its specific receptor. Reverse phase HPLC analysis showed that FITC-conjugation resulted in different FITC-insulin molecules of which only a part could be used in FITC-insulin/FACS analysis of insulin receptors. It is also of note that the $\mathrm{pH}$ optimum for staining with FITC-insulin differed from the conditions for ${ }^{125} \mathrm{I}$ insulin labelling, and it is possible that some of the former investigations with FITC-insulin have been carried out under suboptimal conditions.

The binding of the FITC-insulin preparation used in the present study was fast, saturable, reversible, and displacable by native insulin and by antibodies against insulin receptors, which all are characteristics known from ${ }^{125}$ I-insulin labelling of cells. The FITC-insulin/ FACS method could be used to estimate the total amount of insulin receptor (high affinity plus low affinity), but not to estimate only high affinity receptors, be- 
cause labelling of only these receptors with FITC-insulin would result in a fluorescence signal of the single cell that is below the sensitivity level of the FACS. It should also be noted that the FITC-insulin/FACS method to estimate the number of insulin receptors $\left(R_{0}\right)$ does not rely on a Scatchard analysis in contrast to the ${ }^{125}$ I-insulin method. The two methods nevertheless resulted in comparable data for the total amount of insulin receptors.

The ${ }^{125}$ I-insulin labelling method permits an estimation of the average number of insulin receptors per cell and can therefore not be used to measure variability in the number of insulin receptors between individual cells within a cell population. In contrast, this is feasible with the FITC-insulin/FACS method. The latter method can be used on both fixed and unfixed cells, and subsets of viable cells with different amounts of insulin receptors on the cell surface can therefore be identified and isolated by FACS. This was demonstrated by the analysis of mononuclear blood leucocytes (lymphocytes and monocytes). Monocytes had significant higher amounts of insulin receptors than lymphocytes according to the FITC-insulin/FACS analysis, which is in accordance with ${ }^{125}$ I-insulin studies [25].

The FITC-insulin/FACS method should therefore permit hitherto unfeasible analysis of correlations between insulin receptor expression and other phenotypic characteristics of eukaryotic cells.

Acknowledgements. We thank Dr. A.J.Moody, Novo Industry A/S, for measurements of the biological activity of FITC-insulin, Mr. J.P.Stenvang and Ms. L. Christiansen for expert technical assistance. This work was supported by NIH grants NoCA-29876 and CA35227, The Danish Medical Research Council, The Danish Cancer Society, and The Novo Foundation.

\section{References}

1. Olsson $L$ (1983) Phenotypic diversity in leukemia cell populations. Cancer Metastasis Rev 2: 153-163

2. Kennett RH, McKeavn TJ, Bechtol KB (1983) Monoclonal antibodies against human tumor-associated antigens. In: Kennett RH, McKearn TJ, Bechtol KB (eds) Monoclonal Antibodies. Plenum, New York, pp 155-168

3. Scatchard G (1949) The attraction of proteins for small molecules and ions. Ann NY Acad Sci 51: 660-672

4. Klotz JM (1982) Number of receptor sites from Scatchard graphs: facts and fantasies. Science 217: 1247-1249

5. De Meyts $P(1976)$ Insulin and growth hormone receptors in human cultured lymphocytes and peripheral blood monocytes. In: Blecher M (ed) Methods in receptor research. Marcel Decker, New York, Basel, pp 301-383

6. Bohn B (1976) High-sensitivity cytofluorometric quantitation of lectin and hormone binding to surfaces of living cells. Exp Cell Res 103: 39-46

7. Bohn B, Manske W (1980) Application of flow cytofluorometry to ligand binding studies on living cells: practical aspects and recommendations for calibration and data processing. Flow Cytometr 4 : 227-232

8. Murphy RF, Powers S, Verderame M, Cantor CR, Pollack R (1982) Flow cytofluorometric analysis of insulin binding and internalization by Swiss 3 T3 cells. Cytometry $6: 402-406$
9. Schechter Y, Schlessinger J, Jacobs S, Chang K-J, Cuatrecasas P (1975) Fluorescent labeling of hormone receptors in viable cells: Preparation and properties of highly fluorescent derivatives of epidermal growth factor and insulin. Proc Natl Acad Sci USA 75: 2135-2139

10. Schlessinger J, Schechter Y, Willingham MC, Pastan I (1978) Direct visualization of binding, aggregation, and internalization of insulin and epidermal growth factor on living fibroblastic cells. Proc Natl Acad Sci USA 75: 2659-2663

11. Kosmakos FC, Roth J (1980) Insulin-induced loss of the insulin receptor in IM-9 lymphocytes. J Biol Chem 255: 9860-9869

12. Salzman GC, Crowell JM, Martin JC, Trujillo TT, Romeo A, Mullaney PF, La Bauve PM (1975) Cell classification by laser light scattering: Identification and separation of unstained leukocytes. Acta Cytologica 19: 374-377

13. Sundström C, Nilsson K (1976) Establishment and characterization of a human histiocytic lymphoma cell line (U-937). Int J Cancer 17: 565-577

14. Gallagher R, Collins S, Trufillo J, McCredie K, Ahearn M, Tsai S, Metzgar R, Anlakh G, Ting R, Ruscetti F, Gallo RC (1979) Characterization of the continuous differentiating myeloid cell line (HL-60) from a patient with acute promyelocytic leukemia. Blood 54: $713-733$

15. Olsson L, Ktonstrom $\mathrm{H}$, Cambon-de-Mouzon A, Honsik CJ, Brodin T, Jacobsen B (1983) Antibody producing human-human hybridomas. I. Technical aspects. J Immunol Methods 61: 17-32

16. Klein E, Klein G, Nadkarni JS, Wigzell H, Clifford P (1968) Surface IGM Kappa specificity on a Burkitt lymphoma cell in vivo and in derived culture lines. Cancer Res 28: 1300-1310

17. Fahey JL, Byell DN, Sox HC (1971) Proliferation and differentiation of lymphoid cells: Studies with human lymphoid cell lines and immunoglobulin synthesis. Ann NY Acad Sci 190: 221-234

18. Bromer WW, Sheehan SK, Berns AW, Arquilla ER (1967) Preparations and properties of fluoresceinthiocarbamyl. Biochemistry $6: 2378-88$

19. Gavin JR III, Gordon P, Roth J, Archer JA, Buell DN (1973) Characteristics of the human lymphocyte insulin receptor. J Biol Chem 248: 2202-2207

20. Moody AJ, Stan MA, Stan M, Gliemann J (1974) A simple free fat cell bioassay for insulin. Horm Metab Res 6: 12-16

21. Pedersen O, Hjøllund E, Beck-Nielsen H, Kromann H (1981) Diabetes Mellitus caused by insulin receptor blockade and impaired sensitivity to insulin. New Engl J Med 304: 1085-1088

22. Ouchterlony $\dddot{O}$ (1958) Diffusion-in-gel methods for immunological analysis. In: Progress in allergy, vol 5. Kallos $\mathrm{P}(\mathrm{ed})$ Karger, Basel, New York, pp 1-78

23. Czech M (1982) Cellular dynamics of insulin action. Fed Proc 41: $2717-2718$

24. Janossy G, Francis GE, Capellaro D, Goldstone AH, Greaves MF (1978) Cell sorter analysis of leukemia associated antigens on human myeloid precursors. Nature 276: 176-178

25. Schwartz RH, Bianco AR, Handweger BS, Kahn RC (1975) Demonstration that monocytes rather than lymphocytes are the insulin binding cells in preparations of peripheral blood mononuclear leukocytes: implications for studies of insulin-resistant states in man. Proc Natl Acad Sci USA 72: 474-478

Received: 2 April 1985

and in revised form: 13 August 1985

Professor L. Olsson

Cancer Biology Laboratory

Medical Department A

State University Hospital

Rigshospitalet

9 , Blegdamsvej

DK-2100 Copenhagen

Denmark 